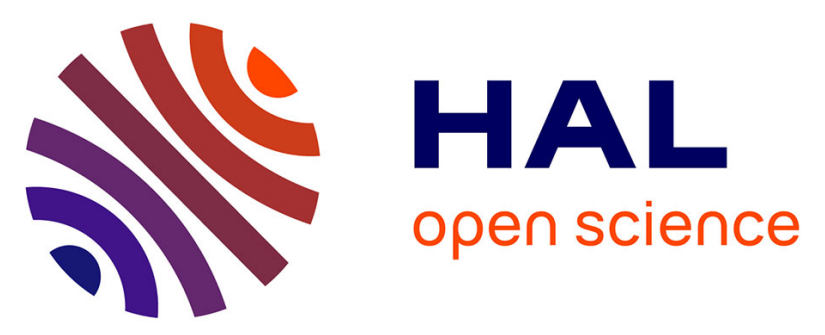

\title{
Human Impact on the Morpho-Sedimentary Evolution on the Coastal Deltaic Zones (Case of Application: Artificial Canal of Medjerda River, Tunisa)
}

Thouraya Benmoussa, Oula Amrouni, Abderraouf Hzami, Laurent Dezileau, Gil Mahe, Saadi Abdeljaouad

\section{To cite this version:}

Thouraya Benmoussa, Oula Amrouni, Abderraouf Hzami, Laurent Dezileau, Gil Mahe, et al.. Human Impact on the Morpho-Sedimentary Evolution on the Coastal Deltaic Zones (Case of Application: Artificial Canal of Medjerda River, Tunisa). Kallel A.; Ksibi M.; Ben Dhia H.; Khélifi N. Recent Advances in Environmental Science from the Euro-Mediterranean and Surrounding Regions. EMCEI, Springer, pp.1701-1703, 2018, 10.1007/978-3-319-70548-4_495 . hal-01861460

\author{
HAL Id: hal-01861460 \\ https://hal.science/hal-01861460
}

Submitted on 11 Dec 2019

HAL is a multi-disciplinary open access archive for the deposit and dissemination of scientific research documents, whether they are published or not. The documents may come from teaching and research institutions in France or abroad, or from public or private research centers.
L'archive ouverte pluridisciplinaire HAL, est destinée au dépôt et à la diffusion de documents scientifiques de niveau recherche, publiés ou non, émanant des établissements d'enseignement et de recherche français ou étrangers, des laboratoires publics ou privés. 


\title{
Human Impact on the Morpho-Sedimentary Evolution on the Coastal Deltaic Zones (Case of Application: Artificial Canal of Medjerda River, Tunisa)
}

\author{
Thouraya Benmoussa, Oula Amrouni, Abderraouf Hzami, Laurent Dezileau, Gil Mahe, and Saâdi \\ Abdeljaouad
}

\section{Introduction}

Shorelines are defined as an interface where natural, anthropogenic, socio-economic constraints are exacerbated and constantly changing. The study of coastal environments linked to different global rivers is all the more important as they can be considered as markers of the evolution of sedimentary contributions in marine environments in relation to climatic as well as human variations (Milliman and Meade 1983; Syvitski 2011). The evolution of the nearshore sediment distribution is related to the variability of hydrodynamic forcing and sediment availability in coastal areas (Amrouni and al. 2014). The study area constitutes the coastal alluvial plain of the Medjerda River (Antiquités africaines 1995), the western bay of the Gulf of Tunis. It receives the majority of the terrigenous inputs feeding its coast (Ouesalti et al. 2004). The mainly anthropogenic activities influencing the evolution of the northern coast sediment distribution of the Gulf of Tunis is

T. Benmoussa $(\bowtie) \cdot$ A. Hzami $\cdot$ S. Abdeljaouad Laboratory of Mineral Resource and Environment, Faculty of Science, University of Tunis El-Manar, The Gulf of Tunis, Tunisia e-mail: benmoussa_thouraya@yahoo.fr

A. Hzami

e-mail: abderraoufhzami@gmail.com

S. Abdeljaouad

e-mail: saadi_abdeljaouad@yahoo.fr

O. Amrouni

Laboratory of Marine Environment, National Institute of Marine

Science and Technology, The Gulf of Tunis, Tunisia

e-mail: oulabz@yahoo.fr

\section{Dezileau}

University of Montpellier II, HDR-Géosciences, Montpellier, France

e-mail: laurent.dezileau @gm.univ-montp2.fr

G. Mahe

UMR HydroSciences Montpellier/IRD, Montpellier, France

e-mail: gilmahe@hotmail.com the construction of several dams on the Medjerda-River (Louati et al. 2015).

\section{Materials and Methods}

The methodology was based on sedimentological investigation completed by spatial monitoring carried out on the mouth and the nearshore seafloor of the new Medjerda River (Since 1939). A surface sediment sampling campaign was conducted in June 2014. A total of 70 samples were taken respectively northern and southern to the new mouth of the Medjerda-River. Four short sediment cores (CEM-1: $168 \mathrm{~cm}),(\mathrm{CEM}-2: 80 \mathrm{~cm}),(\mathrm{CEM}-3: 42 \mathrm{~cm})$ and (CEM-4: $50 \mathrm{~cm}$ ) were collected in August and October 2016, respectively from the central front of delta, on the levee deposit, on the alluvial plain deposit and on the beach of Medjerda-Raouad (Antiquités africaines 1995). All of the submarine samples were subjected to the grain size analysis at INSTM institute. The grain size parameters $(\mathrm{Mz}, S k i, s-$ tandard deviation, $\mathrm{Ku}$ ) were calculated according to the method of Folk and Ward (1957). The determination of transport types and sedimentary facies was carried out using the CM diagram method of Passega (1964); Bravard and Peiry (1999). A high resolution multi-proxy study was undertaken on the cores in the UM, HDR-laboratory. The grain-size analysis was carried out using a Beckman Coul$\operatorname{ter}^{\circ}$ LS 13 320. The geochemical analysis was carried out on the sedimentary material using the X-ray Fluorescence, based on ${ }^{210 \mathrm{P}} \mathrm{b}$ and ${ }^{137} \mathrm{Cs}$ by Gamma spectrometry in order to establish a chronology of the geomorphological evolution of the new delta of Medjerda during the last century. The Principal Component Analysis (PCA) was carried out through the XLSAT-2016 software. The monitoring of the morphological change was established by the spatial analysis of digital data (aerial photographs, topographic maps and satellite imageries) changes between 1936-2016 with the ArcGIS 10.2 software. 


\section{Results and Discussion}

\subsection{Longshore Evolution of Grain Size of Submarine Samples}

The summer longitudinal grain size evolution of marine sediments shows a decreasing trend from south to north. Indeed, the mean grain size (Me) from south to north of the new mouth varies respectively from 450 to $250 \mu \mathrm{m}$, and $\mathrm{Mz}$ is from the range of 1.18-1.98 $\Phi$ respectively. The finest tail toward the northern edge of the Medjerda nearshore is related to the wave dominated action, obviously the south-east summer direction. However, The coastal drift dominant and responsible for sediment transport on the northern coast of the Gulf of Tunis is NW-SE direction (El Arrim 1996). Although recent studies (Amrouni et al. 2014), showed an antagonistic seasonal action of the South-eastern. To the north. As well, Gulf of Tunis bay shows a seasonal variation of $18 \%$ of the summer South-East waves (in 2016).

\subsection{Grain Size and Geochemical Evolution of Sediment Cores}

The high-resolution $(1 \mathrm{~cm})$ grain size analysis of the cores shows a spatial variability. The CEM1 core shows two distinctive sedimentary units. The layer of fine sand (D50 $=98 \mu \mathrm{m})$, is surmounted by clay layer which are intercalated by silty laminas. The CEM 2 core reveals the same sedimentary units but is marked by wider transition layer from which the sediment became a fine-silty distribution. The core CEM3 shows that its basal part is formed of coarser sand $(\mathrm{D} 50=228 \mu \mathrm{m})$. The CEM4 core shows two sedimentary units. A basal part formed of clay surmounted by a layer of medium to coarse sand (D50 $=315 \mu \mathrm{m})$. The mean grain size evolution on the historical beach profile (before clay deposition) shows a decreasing trend from the historical beackshore (CEM-3) to nearshore (CEM-1).

The geochemical results show varying concentrations of chemical elements such as $\mathrm{Fe}, \mathrm{K}, \mathrm{Al}, \mathrm{Rb}, \mathrm{Nb}, \mathrm{Cr}, \mathrm{Ti}, \mathrm{Ba}, \mathrm{Ca}$, $\mathrm{Sr}, \mathrm{Zr}, \mathrm{V}$, and potentially toxic metal trace elements such as $\mathrm{Pb}, \mathrm{Zn}$ and $\mathrm{As}$ in the sedimentary cores. The Principal Component Analysis (PCA) of the chemical elements shows the presence of 3 poles: a pole of terrigenous elements $(\mathrm{Fe}$, $\mathrm{K}, \mathrm{Al}, \mathrm{Rb}, \mathrm{Cr}, \mathrm{Ti})$, a pole of marine elements $(\mathrm{Ca}, \mathrm{Zr}, \mathrm{Sr})$ and a pole of the pollutant minerals $(\mathrm{Zn}, \mathrm{Pb}$ and $\mathrm{As})$. The evolution of the contents of chemical elements in the sedimentary column reveals a good correlation with the granulometric analysis. The marine tracers $(\mathrm{Ca}, \mathrm{Sr})$ show a significant decreasing concentration in the clay layers compared to their rate in the sandy one. The rate in terrigenous elements is higher in the fine sediments. On the other side, the chemical pollutants ( $\mathrm{Zn}, \mathrm{Pb}$ and $\mathrm{As}$ ) show significant peaks especially in the clay deposits. The granulometric and geochemical analysis of the sediment cores shows that the progradation of a new delta at the new mouth of the artificial Medjerda-River was manifested by the fine detrital deposits (Silt and clay). The grain size correlation established from the backshore to the nearshore shows that the historical sandy beach (CEM3 core base) was behind the current shoreline (in the historical backshore area). The past nearshore was illustrated by the fine sand in the bottom layer of the CEM1 core. The temporal grain size distribution reveals the marine and the fluvial ones processes governing the evolution of coastal seafloor closer to the deltaic system. In fact, the transition layer is due to active seasonal East-Southeast wave current. The deltaic deposit erosion and the shoreline retreat at the Medjerda delta was manifested by the top layer of medium to coarse biogenic sand presented in the CEM-4 core which surmounted the fluvial clay deposits. The retained fluvial discharge by the dam construction decreases the coarser fraction toward silt to clay deposit.

\subsection{Transport Pattern and Deposit Mechanism}

The sediment samples presented on the RS segment were focused on the CM- image for the lower clay facies of CEM1, CEM2, and CEM3, which implies that a uniform suspension during the deposition of the unit was controlled by fluvial traction currents. The QR segment determined the CM patterns for the lower sandy units of CEM2 and upper unit of the CEM4 core shows the relatively larger Q99 values of sediment, which implies that the sediments are coarser. These deposits moved by saltation represent the reworking of the sand by wave action in the swash and surf zone. Finally the transitional lithologic facies is related to the interaction of fluvial deposit and the marine action closer the deltaic mouth.

\subsection{Historical Evolution of the New Delta of the Medjerda}

The ${ }^{210} \mathrm{~Pb} /{ }^{137} \mathrm{Cs}$-method dating associated with the spatio-temporal monitoring of the diachronic satellite imagery shows that a new delta has been developed at the new 
mouth of the Medjerda since 1950. The sedimentation speed was estimated at $3.32 \mathrm{~cm} \mathrm{an}^{-1}$ between the years 1950 and 1988. The severe erosion of the river mouth ranged to $5 \mathrm{~m} /$ year has been affected between 1988 and 2016 .

\section{Conclusion}

The result shows that the coast of new mouth of Medjerda River passed through two morpho-sedimentary states during the last century.

1. A relatively rapid progradation with a fluvial dominance marked by silt and clay deposits rich in terrigenous chemical elements from the year 1950. This sedimentary evolution of the new delta is manifested by the filling of the old mouth since 1973 flood. The winnowing of finest fraction (clay and silt) provided during the flood event on the delta front, by the active wave current lead to the preferential spatial grain size distribution toward the northern behavior coast.

2. A retrogradation statement since 1988. Indeed, the dominance of clay deposits more than coarser fraction result to the impact of the dam construction of Sidi Salem dam in 1982. Only the finer fractions can feed the coast.

\section{References}

Amrouni O, Hermassi T, Jaouad SA, Messaoudi S. Contribution of Grain-size Trend to Sediment of a Microtidal Beach. Case of the Gulf of Tunis Bay (Cape Ferina-Cape Gammarth, Tunisia). Res J Environ Sci. 2014; 8:161-77.

Antiquités africaines, volumes 21 à 32, éd. Centre national de la recherche scientifique, Paris, 1995, p. 37.

Bravard J-P, Peiry J-L. The CM pattern as a tool for the classification of alluvial suites and floodplains along the river continuum. In: Marrott SB, Alexander J, editors, Floodplains: interdisciplinary approaches. Geol Soc Spec Publ. 1999; 163: 259-68.

El Arrim A. Étude d'impact de la dynamique sédimentaire sur la stabilité du littoral du Golfe de Tunis. Doctorat de spécialité. 1996; $203 \mathrm{pp}$.

Folk RL, Ward WC. Brazos River bar, a study in the significance of grain size parameters. J Sediment Petrol. 1957;27:514.

Louati M, Saïdi H, Zargouni F. Shoreline change assessment using remote sensing and GIS techniques: a case study of the Medjerda delta coast, Tunisia. Arab J Geosci. 2015;8:4239.

Milliman R, Meade H. World-wide delivery of river sediment to the oceans, John D. J Geol. 1983;91(1):1-21.

Ouesalti A, Charfi F, Baccar F. Presentation of the Tunisian site: la basse vallée de Oued Medjerda et la lagune de Ghar El Melh. Water Demand Integration (WADI project), Fifth International Meeting INCO-CT-2005-015226, 6-9 December: 26. 2004.

Passega R. Grain-size representation by CM patterns as a geological tool. J Sediment Petrol. 1964;34(4):830-47.

Syvitski JPM. Global sediment fluxes to the Earth's coastal ocean. Appl Geochem. 2011; 26:373-4. 